\title{
Antimicrobial activity and Identification of fungus associated Stylissa flabelliformis sponge collected from Menjangan Island West Bali National Park, Indonesia
}

\author{
Erna Prawita Setyowati ${ }^{1 *}$, Sylvia Utami Tunjung Pratiwi ${ }^{1}$, Purwantiningsih ${ }^{1}$, \\ Putu Oka Samirana ${ }^{2}$
}

\begin{abstract}
1Faculty of Pharmacy, Universitas Gadjah Mada (UGM). Jl. Sekip Utara 55281, Yogyakarta, Indonesia

2Dept of Pharmacy, Faculty of Math and Natural Sciences, Udayana

University, Bali, Indonesia
\end{abstract}

Submitted: 08-02-2018

Revised:

Accepted:

*Corresponding author Erna Prawita Setyowati

Email:

erna_prawita@ugm.ac.id

\begin{abstract}
The Fungus is a very important microorganism as a producer of bioactive secondary metabolites. Active substances of microbial origin have been sought through the process of screening methods to obtain antimicrobial compounds. The purpose of this study was to isolate fungi associated with sponge taken from Menjangan Island National Park West Bali (Indonesia) and identify fungi that have antimicrobial activity. Isolation of fungus from sponge was carried out by spread plate method using Saboroud Saline Agar medium. Each fungi will be tested to Staphylococcus aureus ATCC 29213, Escherichia coli ATCC 25922 and Candida albicans ATCC 10231. Identification of fungi is based on the observation of macroscopic, microscopic and also using 16rRNA/ITS phylogeny tree. The results showed that $S$. flabelliformis sponge had 10 fungal isolates. Most of them have antimicrobial activity. The name associated with a sponge fungus is These 10 fungus are Aspergillus flavus strain UPMZ02, Aspergillus fumigatus strain CD1621, Trichoderma reesei strain JCM 2267, Aspergillus nomius strain KUB105, Aspergillus sp. strain TLWK-09, Aspergillus flavus strain MC-10-L, Penicillium sp. strain RMA-2, Aspergillus sp. strain TLWK-09, Aspergillus fumigatus and Trichoderma reesei strain TV221
\end{abstract}

Keyword: Sponge-associated fungi, Stylissa flabelliformis, Staphylococcus aureus, Escherichia coli, Candida albicans

\section{INTRODUCTION}

Sponges are the subject of interesting antibiotic development studies because the sponges form associations with various microbes and are rich in bioactive compounds. Sponges are the largest source of new bioactive compounds than other marine products (Mehbub, et al., 2014). Bioactive compounds obtained from sponges are known to have various activities such as cytotoxic, antimicrobial, anti-inflammatory, antiparasite and others (Proksch, et al., 2002; Setyowati et al, 2016). The bioactive compound on the sponge acts as a self-protection mechanism against the environment. It was surprising to find that many secondary metabolites reported from marine invertebrate are produced by their microorganism symbionts (Thakur and Muller, 2004).
Marine sponges often contain diverse and abundant microbial communities, including bacteria, archaea, microalgae, and fungi. In some cases, these microbial associates comprise as much as $40 \%$ of the sponge volume and can contribute significantly to host metabolism (Taylor, et al., 2007). Correspondingly, the studies of natural products from spongeassociated microorganisms, particularly bacteria and fungi, are also plenty. Secondary metabolites produced by fungi associated with sponges are much larger when compared with secondary metabolites produced by bacteria that associate with sponges. In more detail, Ascomycota dominates the proportion of fungal producer by division (Kim, et al., 2013). The main focus on secondary metabolites produced by fungi is due to their diverse biological activities having both toxic and 
curative effects in maintaining human and veterinary health. More intense studies on marine fungi have been done in the past three decades. These continuous studies revealed that marine fungi are rich sources of bioactive natural products (Ebada and Prosch, 2010; Bills and Gloer, 2016).

Previous study conducted by Setyowati et al. (2004) showed that Stylissa flabelliformis sponge taken from Menjangan Island's waters of the West Bali National Park could produce jaspamide compounds. This compound is highly potent against $C$. albicans and more active than Miconazole nitrate as a comparison, this compound also has cytotoxic power equivalent to vincristine (leukemia cancer drug) in myeloma cells. This compound is usually found from the genus Jaspis sp and has never been found from the species S. flabelliformis. Often metabolites with compound structures similar to those produced from sponges with different taxonomies (Mehbub et al., 2014). This suggests that the structural characteristics of a compound are strongly thought to originate from sponge microorganisms and are responsible for the production of various bioactive compounds (Koopmans, et al., 2009). Therefore it is estimated that some sponge metabolites are produced by symbiotic microorganisms (Thomas, et al., 2010). Antimicrobial assay against fungi associated with $S$. flabelliformis sponge and molecular identification of the sponge fungus was performed in this study.

\section{MATERIAL AND METHODS Sampling and Isolation of the fungal association sponge.}

Specimens of the marine sponge $S$. flabelliformis (Axenellida) were collected from Menjangan Island National Park West Bali (Indonesia) through Scuba diving. Since the stringent surface sterilization procedures have previously proven to be too rigorous for delicate sponge tissues, the sponges were either briefly sterilized for 30s in $70 \% \mathrm{v} / \mathrm{v}$ ethanol followed by three subsequent washing in sterile commercial sea water or merely washed three times in sterile seawater. The sponge tissue was then cut into approximately $1.5 \mathrm{~mm}$ segments and planted on Sabouroud agar growth medium with sea water, $250 \mathrm{ug} / \mathrm{mL}$ chloramphenicol, and cultivated at $25^{\circ} \mathrm{C}$. Emerging fungal mycelia were isolated and taken into the culture.

\section{Antimicrobial activity of fungi}

The concentration of microbes used was $10^{7}$ Colony Forming Unit. The microbial suspension was inoculated into $10 \mathrm{~mL}$ nutrientagar medium (E. coli, S. aureus) and Saboroud Dextrose Agar (C. albicans), then poured into a petri dish.

Sterilized disc paper, sprayed as much as $10 \mu \mathrm{L}$ of fungi methanol extract dissolved with a concentration of $10 \mathrm{mg} / \mathrm{mL}$. As a positive control, $1 \mathrm{mg} / \mathrm{mL}$ of tetracycline was used for antibacterial test and used $1 \mathrm{mg} / \mathrm{mL}$ of griseofulvin for an antifungal test, and methanol as a solvent control. Paper discs were placed on top of pre-prepared solid media. Petri was incubated overnight at $35^{\circ} \mathrm{C}-37^{\circ} \mathrm{C}$. Observed zone barriers formed around the paper disc (Niyomkam, et al., 2010).

\section{Identification of fungi}

Identification of fungi associated sponge was carried out by observing fungi macroscopically, microscopically, and molecularly based on the genetic analysis of partial locus Internal Transcribed Spacer (ITS) ribosomal DNA fungi.

DNA isolation was initiated by growing fungal isolates in Potato Dextrose Broth liquid medium (PDB) and incubated for $72 \mathrm{~h}$. The biomass of the fungal mycelia is further harvested for the DNA extraction process. DNA fungi extraction was performed using PHYTOpure nucleon reagents (Amersham LIFE Science). PCR Amplification on ITS using primer ITS4. Purification of PCR product was performed by PEG precipitation method and continued with cycle sequencing. The results of the sequencing cycle are reversed with ethanol purification method. Analysis of sequence sequencing of nitrogen-based using an automated DNA sequencer (ABI PRISM 3130 Genetic analyzer) (Applied Biosystems). The sequenced raw data was then streamed and dissembled using the Bioedit program. Sequencing data was already assembled at BLAST with genome data registered at DDBJ/DNA Data Bank of Japan or NCBI/National Centre for Biotechnology 


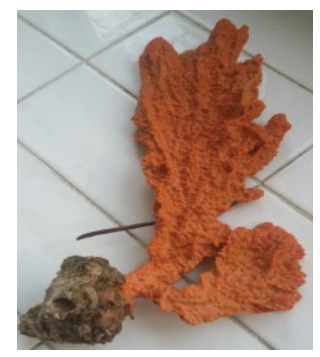

Figure 1. Stylissa flabelliformis sponge.

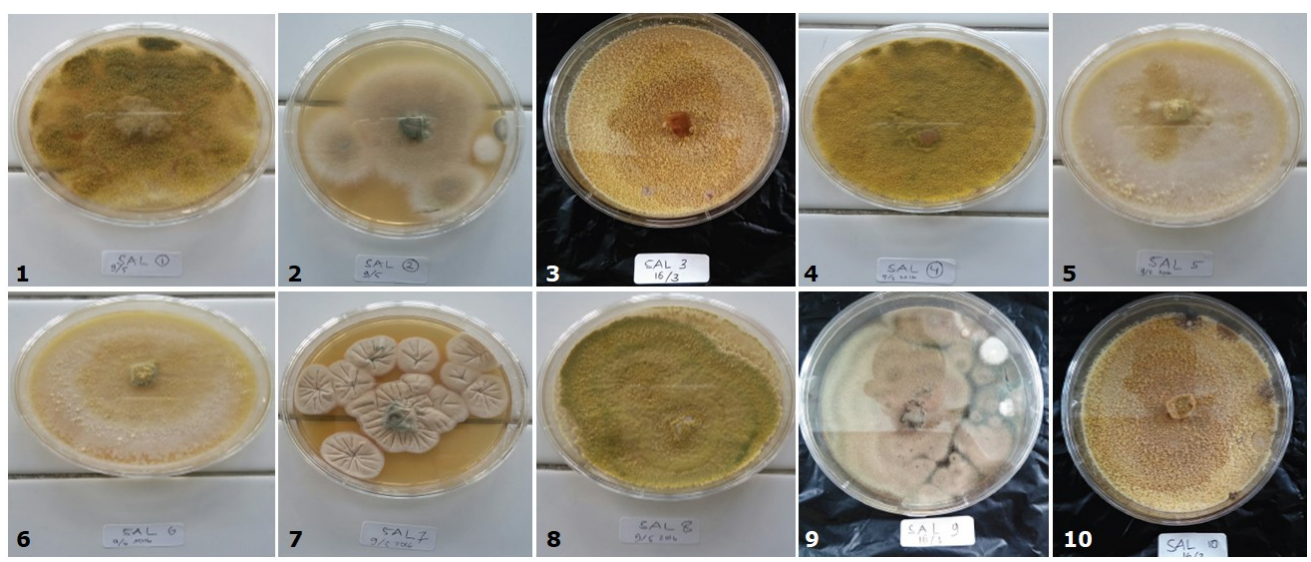

Figure 2. Isolate of fungus from Stylissa flabelliformis

Information to determine which taxon/species has the greatest homology/similarity and is molecularly related (Atashpaza, et al., 2010; Santosa, 2011).

\section{RESULTS AND DISCUSSION}

S. flabelliformis sponges (Figure 1) are red with a thin shape and soft, porous surface with irregular protrusions on the whole body, inside yellowish-white body. Sponge classification is as follows: Kingdom Animalia, Division Porifera, Class Demospongiae, Subclass Ceractinomorpha, Order Halicondrida, Family Axenellida, Genus Stylissa, Species S. flabelliformis (Hooper and Soest, 2002).

The screening was done to obtain the active microbial (fungi) potential. Isolation of fungus from $S$. flabelliformis sponge observed at least 10 fungi as (Figure 2). All of the 10 fungi were then being tested against the 3 kinds of microbes such as Staphylococcus aureus ATCC 29213, Eschericbia coli ATCC 25922 and Candida albicans ATCC 10231. These microbes used are representative of gram-positive bacteria, gramnegative and yeast.
The antimicrobial activity of fungi against several bacteria showed that most of the collected fungi were possible to inhibit the growth of microorganisms tested. Fungi No. 3, 5, 6, 7, 9 and 10 were inhibiting $S$. aureus, C. albicans and E. coli. The fungus has broad-spectrum properties because it can inhibit the growth of almost all tested bacteria and yeast in vitro.

Table I also shows that 7 of the 10 fungi can inhibit Staphylococcus aureus. It is known that $S$. aureus causing various infections, such as acne, ulcers, pneumonia, endocarditis, and implantation of any part of the body (Jawetz et al., 1996). The prevalent treatment to deal with bacterial infections is to use antibiotics such as methicillin, amoxicillin, penicillin, oxacillin, and others. Nonetheless, what seems to be happening is the occurrence of $S$. aureus resistance to these antibiotics. One of the most commonly reported cases of resistance is Methicillin Resistant $S$. aureus (MRSA), a methicillin-resistant $S$. aureus bacterium. The mechanism of methicillin resistance does not depend on the formation of beta-lactamase. However, it is more due to changes in Protein 
Table I. Activity of fungus association sponge against several microbes

\begin{tabular}{|c|c|c|c|c|}
\hline \multirow[b]{2}{*}{$\begin{array}{l}\text { No of fungus } \\
\text { SAL }\end{array}$} & \multicolumn{4}{|c|}{ Activity of fungus against several microbes } \\
\hline & $\begin{array}{c}\text { S. aureus } \\
\text { ATCC } 29213\end{array}$ & $\begin{array}{c}E . \text { coli } \\
\text { ATCC } 25922\end{array}$ & $\begin{array}{c}\text { C. albicans } \\
\text { ATCC } 10231\end{array}$ & $\begin{array}{c}\text { Methicillin Resisten } \\
\text { S. aureus (MRSA) }\end{array}$ \\
\hline 1 & - & - & - & - \\
\hline 2 & $\mathrm{x}$ & - & - & - \\
\hline 3 & $\mathrm{x}$ & $\mathrm{x}$ & $\mathrm{x}$ & - \\
\hline 4 & - & - & - & - \\
\hline 5 & $\mathrm{x}$ & $\mathrm{x}$ & $\mathrm{x}$ & $\mathrm{x}$ \\
\hline 6 & $\mathrm{x}$ & $\mathrm{x}$ & $\mathrm{x}$ & $\mathrm{x}$ \\
\hline 7 & $\mathrm{x}$ & $\mathrm{x}$ & $\mathrm{x}$ & $\mathrm{x}$ \\
\hline 8 & - & - & $x$ & - \\
\hline 9 & $x$ & $x$ & $x$ & $x$ \\
\hline 10 & $\mathrm{x}$ & $x$ & $\mathrm{x}$ & $x$ \\
\hline
\end{tabular}

$\mathrm{x}=$ it has antimicrobial activity

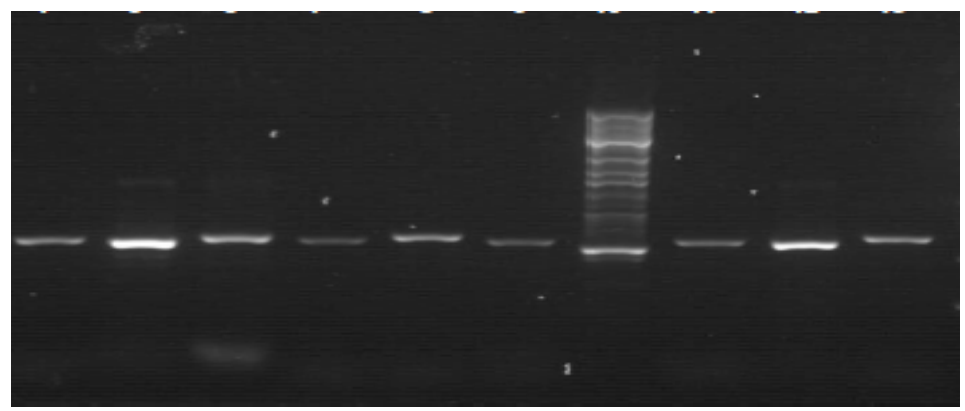

Figure 3. Isolated DNA from Sal 1; 2. Isolated DNA from Sal 2; 3. Isolated DNA from Sal 3; 4. Isolated DNA from Sal 4; 5. Isolated DNA from Sal 5; 6. Isolated DNA from Sal 6; 7. Isolated DNA from Sal 7; 8. Isolated DNA from Sal 8; 9. Isolated DNA from Sal 9; 10. Isolated DNA from Sal 10. All DNA samples were loaded at concentration of $1 / 100$ with condition $0.8 \%$ agarose gel. Amount of DNA ladder loaded per lane: $0.2 \mathrm{ug}$ each. Volume of sample loaded per lane : $1 \mathrm{uL}$ each.

Binding Penicillins (PBPs), a penicillin-receiving protein that occurs as a result of chromosome mutations (Hugo and Russel, 2011). There are 5 fungi that can inhibit the growth of three microbes. In addition, sponge-derived strain collections that comprise isolates that tested negative for antimicrobial activity at first may have done so, because the compound of interest is not produced under standard laboratory conditions (Indraningrat, et al, 2016).

\section{Result of molecular identification Sequencing by ITS rDNA Isolate}

Figure 3. Isolated DNA from Sal 1; 2. Isolated DNA from Sal 2; 3. Isolated DNA from Sal 3; 4. Isolated DNA from Sal 4; 5. Isolated DNA from Sal 5; 6. Isolated DNA from Sal 6; 7. Isolated DNA from Sal 7; 8. Isolated DNA from Sal 8; 9. Isolated DNA from Sal 9; 10. Isolated DNA from Sal 10. All DNA samples were loaded at concentration of $1 / 100$ with condition $0.8 \%$ agarose gel. Amount of DNA ladder loaded per lane: 0.2ug each. Volume of sample loaded per lane : $1 \mathrm{uL}$ each.

Sal 1: Based on BLAST results on the NCBI database against the ribosomal RNA 18S sequence Gene sample number 1702.00467 obtained homology of $100 \%$ with Aspergillus flavus strain UPMZ02 18S ribosomal RNA gene, partial sequence; Internal transcribed spacer 1, 5.8S ribosomal RNA gene, and internal transcribed spacer 2, complete sequence; And $28 \mathrm{~S}$ ribosomal RNA gene, partial sequence 


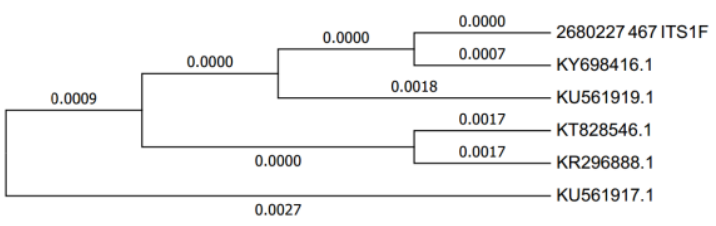

Figure 4. Phylogeny tree of fungi Sal 1

KY698416.1 Aspergillus flawus strain UPMZ02 18S ribosomal RNA gene partial sequence internal transcribed spacer $15.8 \mathrm{~S}$ ribosomal RNA gene and internal transcribed spacer 2 complete sequence and $28 \mathrm{~S}$ re; KU561919.1 Aspergillus flavus strain aC4 internal transcribed spacer 1 partial sequence $5.8 \mathrm{~S}$ ribosomal RNA gene and internal transcribed spacer 2 complete sequence and 28S ribosomal RNA gene partial e; KT828546.1 Aspergillus flavus strain KAU internal transcribed spacer 1 partial sequence $5.8 \mathrm{~S}$ ribosomal RNA gene and internal transcribed spacer 2 complete sequence and $28 \mathrm{~S}$ ribosomal RNA gene partial e; KR296888.1 Aspergillus flawns strain PUXXFS06 18S ribosomal RNA gene partial sequence internal transcribed spacer $15.8 \mathrm{~S}$ ribosomal RNA gene and internal transcribed spacer 2 complete sequence and 28e; KU561917.1 Aspergillus flavus strain sM4 internal transcribed spacer 1 partial sequence 5.8S ribosomal RNA gene and internal transcribed spacer 2 complete sequence and $28 \mathrm{~S}$ ribosomal RNA gene partial (Figure 4).

Sal 2: Based on BLAST results on the NCBI database on the ribosomal RNA 18S sequence Gene sample number 1702.00468 obtained a homology of $99 \%$ with Aspergillus fumigatus strain CD1621 18S ribosomal RNA gene, partial sequence; Internal transcribed spacer 1, 5.8S ribosomal RNA gene, and internal transcribed spacer 2, complete sequence; And $28 \mathrm{~S}$ ribosomal RNA gene, partial sequence

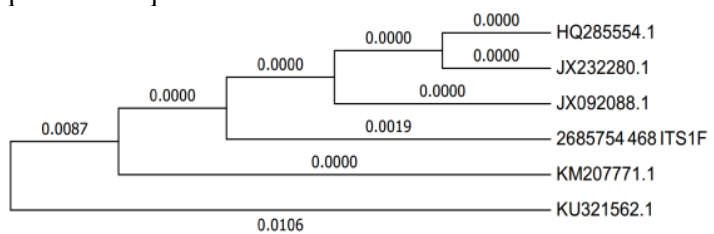

Figure 5. Phylogeny tree of fungi Sal 2

HQ285554.1 Aspergillus fumigatus strain DS-C3 18S ribosomal RNA gene partial sequence; JX232280.1 Aspergillus fumigatus strain SGE69 18S ribosomal RNA gene partial sequence; JX092088.1 Aspergillus fumigatus strain CD1621 18S ribosomal RNA gene partial sequence; KM207771.1 Aspergillus fumigatus strain SK1 internal transcribed spacer 1 partial sequence 5.8S ribosomal RNA gene; KU321562.1 Aspergillus fumigatus strain 004 internal transcribed spacer 1 partial sequence $5.8 \mathrm{~S}$ ribosomal RNA gene (Figure 5).

Sal 3: Based on BLAST results on the NCBI database on the ribosomal RNA 18S sequence Gene sample number 1702.00469 obtained homology of $100 \%$ with Trichoderma reesei genes for $18 \mathrm{~S}$ rRNA, ITS1, 5.8S rRNA, ITS2 and $28 \mathrm{~S}$ rRNA, partial and complete sequence, strain JCM 2267

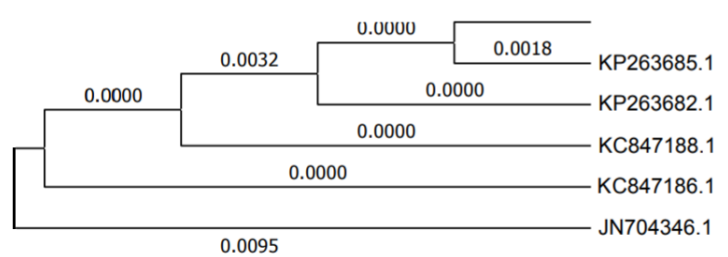

Figure 6. Phylogeny tree of fungi Sal 3

KP263685.1 Trichoderma reesei strain JCM 2267 internal transcribed spacer 1 partial sequences $5.8 \mathrm{~S}$ ribosomal RNA gene; KC847188 Trichoderma reesei strain IPBCC06 $32518 \mathrm{~S}$ ribosomal RNA gene partial sequence internal transcribed spacer $15.8 \mathrm{~S}$ ribosomal RNA gene; KC847186 Trichoderma reesei strain IPBCC93 $26018 \mathrm{~S}$ ribosomal RNA gene partial sequence internal transcribed spacer $15.8 \mathrm{~S}$ ribosomal RNA gene; JN704346.1 Hypocrea jeccorina voucher HR241489 1 partial $18 \mathrm{~S}$ ribosomal RNA gene partial sequence internal transcribed spacer 1 5.8S ribosomal RNA gen (Figure 6).

Sal 4: Based on BLAST results on the NCBI database on the ribosomal RNA $18 \mathrm{~S}$ sequence Gene sample number 1702.00470 obtained a homology of $100 \%$ with Aspergillus nomius strain KUB105 18S ribosomal RNA gene, partial sequence; Internal transcribed spacer 1, 5.8S ribosomal RNA gene, and internal transcribed spacer 2, complete sequence; And $28 \mathrm{~S}$ ribosomal RNA gene, partial sequence

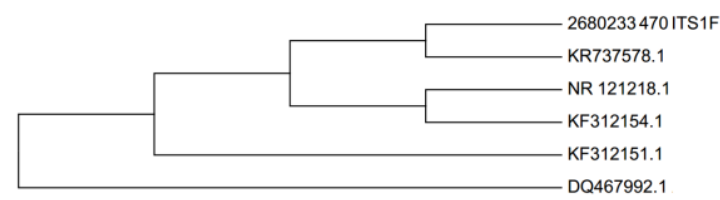

Figure 7. Phylogeny tree of fungi Sal 4

KR737578.1 Aspergillus nomius strain KUB105 18S ribosomal RNA gene partial sequence internal transcribed spacer $15.8 \mathrm{~S}$ ribosomal RNA gene and internal transcribed spacer 2 complete sequence and $28 \mathrm{~S}$ re; NR 121218.1 Aspergillus nomius NRRL 13137 
ITS region from TYPE material; KF312154.1 Aspergillus nomius strain JA2 internal transcribed spacer 1 partial sequence 5.8S ribosomal RNA gene and internal transcribed spacer 2 complete sequence and 28S ribosomal RNA gene partial e; KF312151.1 Aspergillus nomius strain P3 internal transcribed spacer 1 partial sequence $5.8 \mathrm{~S}$ ribosomal RNA gene and internal transcribed spacer 2 complete sequence and 28S ribosomal RNA gene partial se; DQ467992.1 Aspergillus nomius strain KS2 18S ribosomal RNA gene partial sequence internal transcribed spacer $15.8 \mathrm{~S}$ ribosomal RNA gene and internal transcribed spacer 2 complete sequence and $28 \mathrm{~S}$ ribose (Figure 7 ).

Sal 5: Based on BLAST results on the NCBI database on the ribosomal RNA $18 \mathrm{~S}$ sequence Gene sample number 1702.00471 obtained a homology of $100 \%$ with Aspergillus sp. strain TLWK-09 internal transcribed spacer 1, partial sequence; $5.8 \mathrm{~S}$ ribosomal RNA gene and internal transcribed spacer 2, complete sequence; And large ribosomal subunit of RNA gene, partial sequence

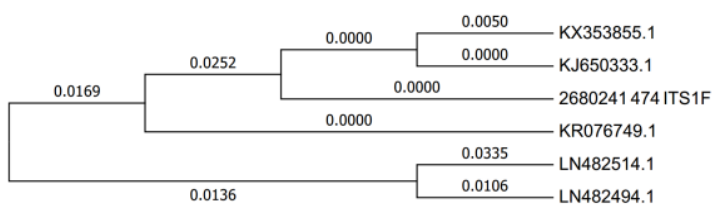

Figure 8. Phylogeny tree of fungi Sal 5

KX353855.1 Aspergillus sp. strain TLWK-09 internal transcribed spacer 1 partial sequence $5.8 \mathrm{~S}$ ribosomal RNA gene; KJ650333.1 Aspergillus oryzae strain SCIM1 internal transcribed spacer 1 partial sequence 5.8S ribosomal RNA gene; KR076749.1 Aspergillus flavus strain meijun2 internal transcribed spacer 1 partial sequence $5.8 \mathrm{~S}$ ribosomal RNA gene; LN482514.1 Aspergillus flavus genomic DNA containing ITS1 5.8S rRNA gene and ITS2 strain TUHT118; LN482494.1 Aspergillus flavus genomic DNA containing ITS1 5.8S rRNA gene and ITS2 isolate TUHT98 (Figure 8).

Sal 6: Based on BLAST results on the NCBI database against the ribosomal RNA 18S sequence Gene sample number 1702.00472 obtained homology of $100 \%$ with Aspergillus flavus strain MC-10-L internal transcribed spacer 1, partial sequence; $5.8 \mathrm{~S}$ ribosomal RNA gene and internal transcribed spacer 2, complete sequence; And 28S ribosomal RNA gene, partial sequence (Figure 7).

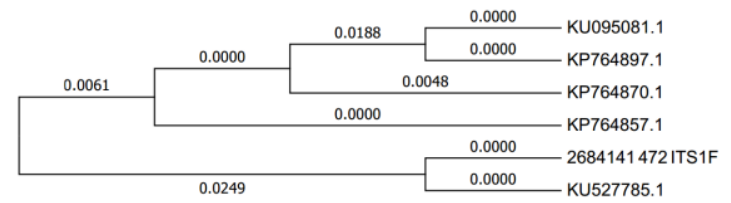

Figure 9. Phylogeny tree of fungi Sal 6 KU095081.1 Aspergillus oryzae strain J12 internal transcribed spacer 1 partial sequence $5.8 \mathrm{~S}$ ribosomal RNA gene; KP764897.1 Aspergillus flavus isolate AfKSA13-15 internal transcribed spacer 1 partial sequence 5.8S ribosomal RNA gene; KP764870.1 Aspergillus flavus isolate AfKSA13-04 internal transcribed spacer 1 partial sequence $5.8 \mathrm{~S}$ ribosomal RNA gene; KP764857.1 Aspergillus oryzae isolate AoKSA13-01 internal transcribed spacer 1 partial sequence 5.8S ribosomal RNA gene; KU527785.1 Aspergillus flavus strain MC-10-L internal transcribed spacer 1 partial sequence $5.8 \mathrm{~S}$ ribosomal RNA gene (Figure 9).

Sal 7: Based on BLAST results on the NCBI database against the ribosomal RNA 18S sequence Gene sample number 1702.00473 obtained homology of $99 \%$ with Penicillium sp. strain RMA-2 internal transcribed spacer 1, partial sequence; $5.8 \mathrm{~S}$ ribosomal RNA gene and internal transcribed spacer 2, complete sequence; And large ribosomal subunit of RNA gene, partial sequence

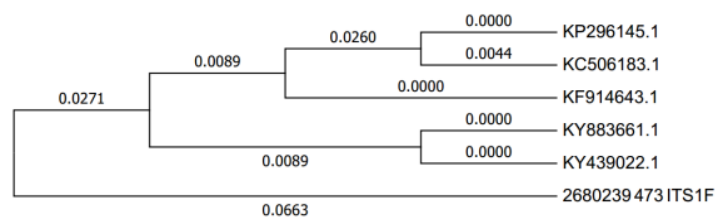

Figure 10. Phylogeny tree of fungi Sal 7

KP296145.1 Penicillium griseofulvum isolate 018 internal transcribed spacer 1 partial sequence $5.8 \mathrm{~S}$ ribosomal RNA gene; KC506183.1 Fungal sp. AM2013 strain $16 \mathrm{Mp}$ internal transcribed spacer 1 partial sequence $5.8 \mathrm{~S}$ ribosomal RNA gene KF914643.1 Penicillium sp. 4M3 internal transcribed spacer 1 partial sequence $5.8 \mathrm{~S}$ ribosomal RNA gene; KY883661.1 Penicillium sp. strain RMA-2 internal transcribed spacer 1 partial sequence 5.8S ribosomal RNA gene; KY439022.1 Penicillium citrinum strain $1 \mathrm{~S} .12$ internal transcribed spacer 1 partial sequence $5.8 \mathrm{~S}$ ribosomal RNA gene (Figure 10).

Sal 8: Based on BLAST results on the NCBI database on the ribosomal RNA 18S sequence Gene sample number 1702.00474 
obtained a homology of $100 \%$ with Aspergillus sp. strain TLWK-09 internal transcribed spacer 1, partial sequence; $5.8 \mathrm{~S}$ ribosomal RNA gene and internal transcribed spacer 2, complete sequence; And large ribosomal subunit of RNA gene, partial sequence. Figure and fungus identification data for Sal 8 are the same as figure and data in Sal 5 (Figure 8), so Sal 8 is not further elaborated

Sal 9: Based on BLAST results on the NCBI database on the ribosomal RNA 18S sequence Gene sample number 1702.00475 obtained a homology of $100 \%$ with Aspergillus fumigatus small ribosomal subunit RNA gene, partial sequence; Internal transcribed spacer 1, 5.8S ribosomal RNA gene, and internal transcribed spacer 2, complete sequence; And large ribosomal subunit of RNA gene, partial sequence.

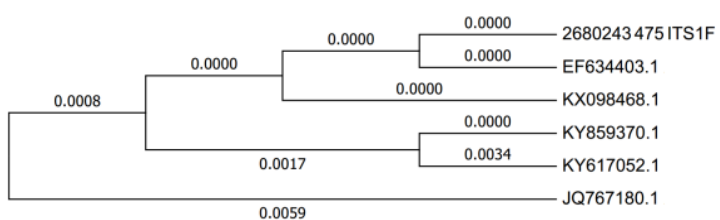

Figure 11. Phylogeny tree of fungi Sal 9

EF634403.1 Aspergillus fumigatus isolate NRRL 35223 18S ribosomal RNA gene partial sequence internal transcribed spacer $15.8 \mathrm{~S}$ ribosomal RNA gene; KX098468.1 Aspergillus fumigatus small subunit ribosomal RNA gene partial sequence internal transcribed spacer $15.8 \mathrm{~S}$ ribosomal RNA gene; KY859370.1 Aspergillus fumigatus isolate 97 6E4 small subunit ribosomal RNA gene partial sequence internal transcribed spacer $15.8 \mathrm{~S}$ ribosomal RNA gene; KY617052.1 Aspergillus fumigatus voucher MHE 24 MC internal transcribed spacer 1 partial sequence $5.8 \mathrm{~S}$ ribosomal RNA JQ767180.1 Aspergillus fumigatus strain ZH1 18S ribosomal RNA gene partial sequence internal transcribed spacer $15.8 \mathrm{~S}$ ribosomal RNA gene and internal transcribed spacer 2 complete sequence and $28 \mathrm{~S}$ (Figure 11).

Sal 10 : Based on BLAST results on the NCBI database on the ribosomal RNA 18S sequence Gene Sal 10 obtained a homology of $99 \%$ with Trichoderma reesei strain TV221 internal transcribed spacer 1, partial sequence; 5.8S ribosomal RNA gene and internal transcribed spacer 2, complete sequence; And $28 \mathrm{~S}$ ribosomal RNA gene, partial sequence.

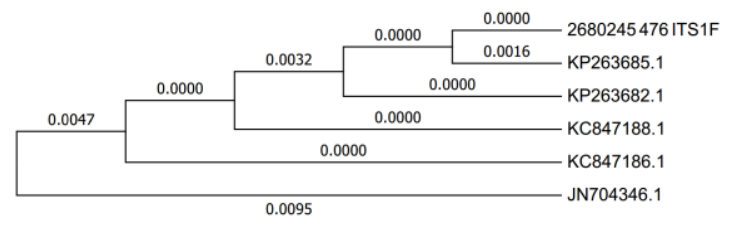

Figure 12. Phylogeny tree of fungi Sal 10 KP263685.1 Trichoderma reesei strain TV221 internal transcribed spacer 1 partial sequence $5.8 \mathrm{~S}$ ribosomal RNA gene; KP263682.1 Trichoderma reesei strain TV217 internal transcribed spacer 1 partial sequence 5.8S ribosomal RNA gene; KC847188.1 Trichoderma reesei strain IPBCC06 325 18S ribosomal RNA gene partial sequence internal transcribed spacer $15.8 \mathrm{~S}$ ribosomal RNA gene; KC847186.1 Trichoderma reesei strain IPBCC93 260 $18 \mathrm{~S}$ ribosomal RNA gene partial sequence internal transcribed spacer $15.8 \mathrm{~S}$ ribosomal RNA gene; JN704346.1 Hypocrea jecorina voucher HR241489.1 partial 18S ribosomal RNA gene partial sequence internal transcribed spacer 1 5.8S ribosomal RNA gen (Figure 12).

From the results of the data above can be seen that the 10 fungi, 7 fungi belong to the genus Aspergillus, 2 fungi belong to the genus Trichoderma and 1 fungi belong to the genus Penicillium. These three genera are included in the Ascomycota division. Although the genus is the same (Aspergillus) not all fungi have antimicrobial effects on the microbes tested. Most fungi of the Ascomycota division having an antimicrobial effect are Aspergillus, as expressed in the Indraningrat et al paper (Indraningrat et al, 2016). Sponge-associated Ascomycota found to produce antimicrobials can be further classified into 12 genera. Of these 12 fungal genera Aspergillus (30\%) and Penicillium (23\%) are currently the two most prominent groups of sponge-associated fungi reported as antimicrobial producers.

\section{CONCLUSION}

S. flabelliformis sponges have 10 fungal isolates. Fungi Sal 3 (Trichoderma reesei strain JCM 2267), Sal 5 (Aspergillus sp strain TLWK09), Sal 6 (Aspergillus flavus strain MC-10-L) and Sal 10 (Trichoderma reesei strain TV221) have antimicrobial activity against E. coli ATCC 25922, S. aureus ATCC 29213 and Candida albicans ATCC 27583. These 10 fungus are Aspergillus flavus strain UPMZ02, Aspergillus 
fumigatus strain CD1621, Trichoderma reesei strain JCM 2267, Aspergillus nomius strain KUB105, Aspergillus sp. strain TLWK-09, Aspergillus flavus strain MC-10-L, Penicillium sp. strain RMA-2, Aspergillus sp. strain TLWK-09, Aspergillus fumigatus and Trichoderma reesei strain TV221.

\section{ACKNOWLEDGMENT}

The author would like to acknowledge the funding support from PUPT-DIKTI Indonesia No: 2331./UN1.P.III/LT/DITLIT/2017.

\section{REFERENCES}

Atashpaza S., Khania S., Barzegaria A., Barara, J., Zununi SVRA, and Omidi Y., 2010, A Robust Universal Method for Extraction of Genomic DNA from Bacterial Species, Microbiology, 79 (4) 538-542.

Bills GF., and Gloer JB., 2016, Biologically Active Secondary Metabolites from the Fungi, Microbiol Spectr, 4(6).

Ebada SS., and Proksch P., 2010, Bioactive Secondary Metabolites from MarineDerived Fungi in Marine Pharmacognosy Trends and Applications Edited by Se_kwon Kim, WILEY-VCH, Verlag GMBH \& Co

Hooper JNA, and van Soest RWM., 2002, Systema Porifera: A Guide to Classification of Sponges, pp: 783-784, volume 1, Kluwer Academic, Plenum Publisher, New York

Hugo WB., Russels AD., 2011, Pharmacentical Microbiology, 8th Ed., 267-268, Blackwell Scientific Publications, Oxford London Edinburgh, Boston Melbourne.

Indraningrat AAg., Smidt H., and Sipkema D., 2016, Bioprospecting SpongeAssociated Microbes for Antimicrobial Compounds, Mar. Drugs 14(5), 87

Jawetz E., Melnick JL., Adelberg EA., Brooks, GF., Butel JS., Ornston LN., 1995, Jawetz Melnick, Adelberg Mikrobiologi Kedokteran, diterjemahkan oleh Nugroho, E., \& Maulany, R.F., 1996, 20th Ed., 208, 211-214, 234-236, Penerbit Buku Kedokteran EGC, Jakarta.

Kim SK., Dewapriya P., and Li YX., 2013, Marine Sponge-Associated Microbes A Source of Biologically Active Metabolites in Marine Pharmacognosy Trends and
Applications Edited by Se_Kwon Kim, WILEY-VCH, Verlag GMBH \& Co

Koopmans M., Martens D., and Wijffels RH., 2009, Towards Commercial Production of Sponge Medicines, Mar Drugs, 7(4): 787-802

Mehbub MF., Lei J., Franco C., Zhang W., 2014, Marine Sponge Derived Natural Products between 2001 and 2010: Trends and Opportunities for Discovery of Bioactives, Mar. Drugs, 12(8), 45394577

Niyomkam P., Kaewbumrung S.,Kaewnpparat S., and Panichayupakaranant P., 2010, Antibacterial activity of Thai herbal extracts on acne involved microorganism, Pharm. Biol., (48) 375-380.

Proksch P, Edrada RA, Ebel R, 2002, Drugs from the seas - current status and microbiological implications, Appl Microbiol Biotech, 59(2-3):125-34

Santosa DA., 2011, Rapid Extraction and Purification of Environmental DNA for Molecular Cloning Applications and Molecular Diversity Studies, Molecular Biotechnology Vol 17, 59-64

Setyowati EP., Jenie UA., Sudarsono, Kardono, LB., 2016, Apoptosis induction of bioactive substance Theonellapeptolide $1 d$ and 1-(tetrabydro-4-bydroxy-5-(bydroxymetbyl) furan-2-yl)-5-methyl pyrimidine-2,4(1H,3H)dione isolated from Kaliapsis sp sponge collection from West Bali National Park Indonesia, J Bio. Scie16 (1-2) 30-36

Setyowati, EP., Sudarsono Wahyuono S., 2004, Uji Sitotoksik dan Uji Antimikroba Senyawa Bioaktif Spons Sylissa flabelliformis, Indonesian J Pharmacy, 15 (2)

Taylor MW., Radax R., Steger D., Wagner M., 2007, Sponge-Associated Microorganism: Evolution, Ecology, and Biotechnological Potential, Microbiol Mol Biol Rev 71(2) 295-347.

Thakur NL., and Müller WEG., 2004, Biotechnological Potential of Marine Sponges, Current Science, 86, 1506-1512

Thomas TRA., Kavlekar DP., and Loka Bharathi PA., 2010, Marine Drugs from Sponge-Microbe Association-A Review, Mar Drugs 8(4) 1417-1468 